\title{
White-tailed Deer Diets from Pastures in Excellent and Poor Range Condition
}

\author{
F.C. BRYANT, C.A. TAYLOR, AND L.B. MERRILL
}

\begin{abstract}
A study was initiated in August, 1975, to examine the forage available to and diet composition of white-tailed deer on pastures of excellent and poor range condition at the Sonora Research Station near Sonora, Texas. Grass and forb standing crop and deer feeding time on these two forage classes were considerably higher on the pasture in excellent range condition than that in poor range condition. Browse standing crop and feeding time was greater from the pasture in poor range condition. The Merrill 4-pasture grazing system appeared to increase the availability and use by deer of grass regrowth. Yearly averages of crude protein and phosphorus were higher in diet samples collected from the pasture in excellent range condition. Digestible energy levels were similar between pastures when averaged over the 1-year period. Digestible energy levels in diets were, however, higher from the excellent condition pasture in every season except winter. In winter, deer fed primarily on the foliage of oak on excellent condition range; but on the pasture in poor range condition, deer used large amounts of foliage and mast from juniper and dead leaves of persimmon in addition to oak foliage. Juniper and persimmon apparently contributed to the higher digestible energy levels observed on the pasture in poor range condition during the winter season. Energy may be a major nutrient limiting deer production on the Edwards Plateau.
\end{abstract}

In pristine times, the Edwards Plateau of Texas was considered a grassland steppe but has since been invaded by woody perennials (Krebs 1972). It now contains a diverse community capable of supporting many kinds of plants and animals. Among the endemic

The authors are assistant professor, Department of Range and Wildlife Management, Texas Tech University, Lubbock 79409, and rescarch associate and professor in charge, Texas Agricultural Experiment Station, Sonora, 76950. At the time of this research Bryant was research assistant, Department of Range Science, Texas A\&M University, College Station. The authors thank Dr. Ed Huston and Barron S. Rector for laboratory analysis at the Texas Agricultural Experiment Station, San Angelo, and Dr. M.M. Kothmann, Department of Range Science. Texas A\&M University, for his advice and support throughout this study. The financial support provided by the Texas Agricultural Experiment Station is gratefully acknowledged.

This report is Technical Article 14598 from the Texas Agricultural Experiment Station.

Manuscript received January 17, 1979. fauna occurs one of the most dense concentrations of white-tailed deer (Odocoileus virginianus) in the world. Economically, ranchers on the Edwards Plateau often make more net profit from marketing hunting privileges for a white-tailed buck than from the sale of a calf. The problem, however, is not in raising a quantity of animals but in producing quality deer. This problem has been magnified both by an over-population of deer and by poor grazing management of livestock that share the range with deer.

White-tailed deer do poorly on ranges stocked heavily with cattle, sheep and goats and grazed continuously year after year. McMahan and Ramsey (1965) reported a period of 8 years without a fawn crop when deer were confined in 38-ha experimental pastures under these conditions. However, deer do in fact survive and even thrive under unconfined conditions because of their remarkable ability to respond to wet years by doubling their population size (Marburger and Thomas 1965). Inadequate harvest of these high populations coupled with poor grazing management practices interact to produce poor quality deer (Teer et al. 1965). Although deer numbers are favorably influenced by proper stocking and deferred-rotation grazing systems (Merrill et al. 1957; Reardon et al. 1978), our objectives were to quantify the relationships of excellent vs. poor condition range in terms of quantity of forage available to deer and the botanical composition and nutritional quality of their diets.

\section{Study Area and Methods}

Two 8-ha study sites were selected at the Texas A\&M University Agricultural Research Station located $45 \mathrm{~km}$ southeast of Sonora, Texas. One study site was selected in a pasture representing excellent range condition and the other poor range condition (Fig. 1). The pastures have had different histories of use and manipulation (Table 1).

Topography of the Sonora Station is rolling with steep breaks along some drainages. Soils are generally stony clays and clay loams. Precipitation averages $61 \mathrm{~cm}$ annually with peaks in May and September. 

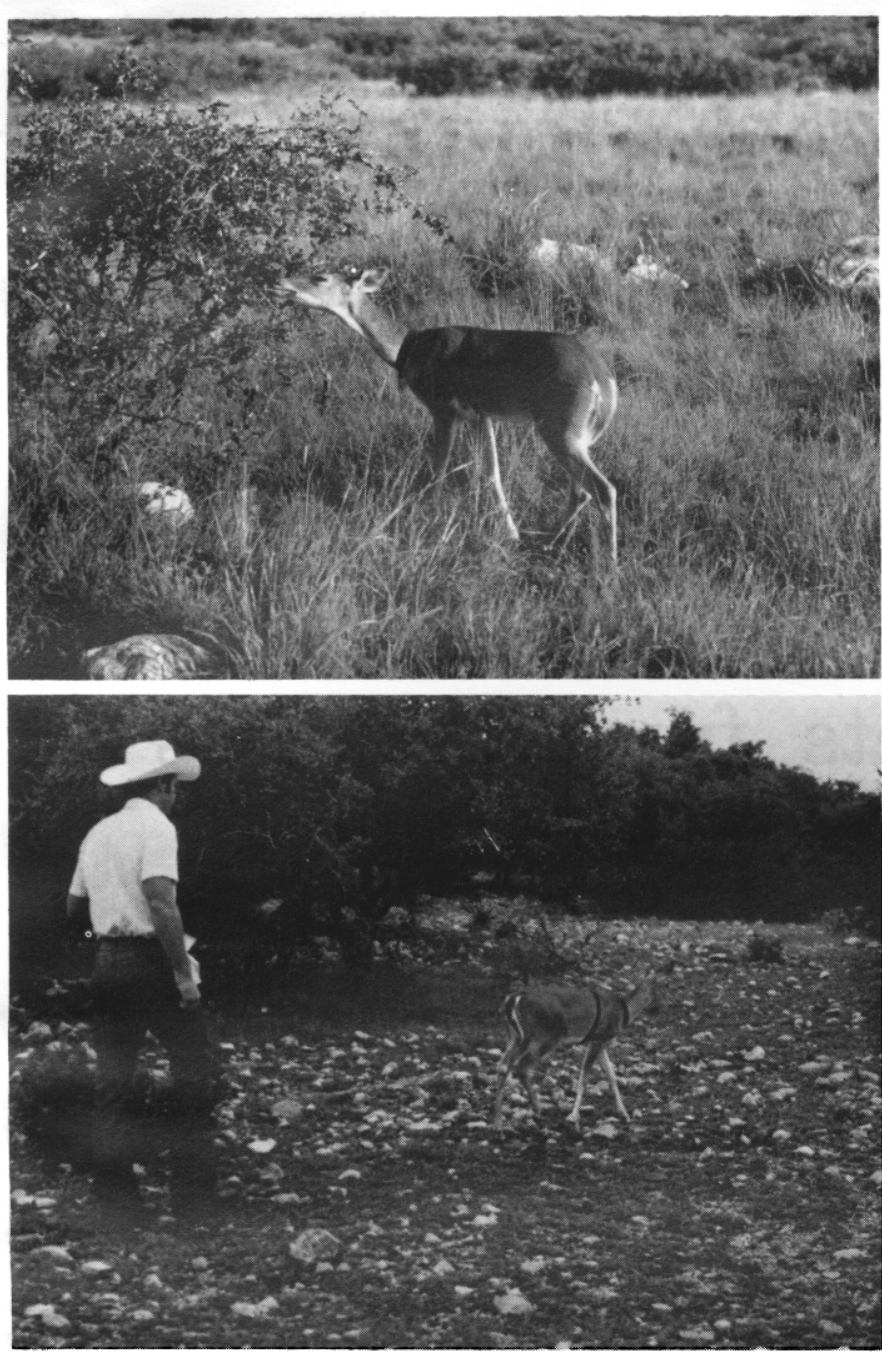

Fig. 1. Study sites in the pastures considered to be in excellent (top) and poor (bottom) range condition.

Forage availability was measured every month on the excellent condition pasture and at five selected periods on the poor condition pasture. Sampling began in August, 1975, and ended in July, 1976. For comparison between pastures, data on available forage are reported only for the five selected periods.

Grass and forb standing crop was estimated using the technique proposed by Goebel et al. (1958) that has been modified by Malechek and Leinweber (1972) and Durham and Kothmann (1977).

Table 1. Past history and characteristics of the pastures in excellent and poor range condition.

\begin{tabular}{|c|c|c|}
\hline Attribute & Excellent condition & Poor condition \\
\hline Range site: & Low stony hill & Low stony hill \\
\hline Soil type: & Tarrant stony clay & Tarrant stony clay \\
\hline $\begin{array}{l}\text { Ratio of cattle, sheep, } \\
\text { and Angora goats: }\end{array}$ & $2: 1: 1$ & $2: 1: 1$ \\
\hline Stocking rate: & & \\
\hline $\begin{array}{l}1948-1969 \\
(1970)\end{array}$ & $\begin{array}{l}1 \mathrm{AU} / 16.2 \text { ha } \\
\text { (Rootplow and seed) }\end{array}$ & $\begin{array}{l}1 \mathrm{AU} / 5.4 \text { ha } \\
\text { (No treatment) }\end{array}$ \\
\hline $1970-1974$ & $1 \mathrm{AU} / 6.5$ ha & $1 \mathrm{AU} / 5.4$ ha \\
\hline $1974-1977$ & $1 \mathrm{AU} / 5.4 \mathrm{ha}$ & $1 \mathrm{AU} / 5.4$ ha \\
\hline Grazing management: & & \\
\hline $1948-1970$ & \multirow{2}{*}{\multicolumn{2}{|c|}{$\begin{array}{l}\text { Continuous, yearlong Continuous, yearlong } \\
\text { Merrill, 4-pasture, 3-herd Continuous, yearlong }\end{array}$}} \\
\hline 1970-present & & \\
\hline Deer density:! & $1 \mathrm{deer} / 5.2 \mathrm{ha}$ & $1 \mathrm{deer} / 8.1$ ha \\
\hline
\end{tabular}

${ }^{1}$ Data from Reardon et al. (1978).
Browse standing crop on excellent condition range was estimated by multiplying mean weight per plant $X$ plants per ha as described by Bryant and Kothmann (1979). Because mature trees existed on the poor condition range, browse standing crop was evaluated by projecting the Goebel et al. (1958) method to all browse species, as explained by Malechek and Leinweber (1972).

Botanical composition of diets was estimated by observing two tame white-tailed deer and using the feeding minutes technique for relative comparisons. Bjugstad et al. (1970) have described the technique and its limitations. One-hour observation periods were conducted for 5 consecutive days each month. Because of conflicts with other research, the poor condition pasture was sampled with the same deer 2 weeks after the 5-day sampling period in the excellent condition pasture. Preference indices for important plant species are reported within months only for the excellent condition pasture. Indices were derived using the formula from Durham and Kothmann (1977):

$$
\mathrm{PI}=\frac{\% \text { of feeding time }-\% \text { available }}{\% \text { of feeding time }+\% \text { available }} \times 10
$$

To determine nutrient content of diets for each daily grazing period, samples of plant species and their plant parts were handplucked as the deer grazed to simulate the feeding behavior of each deer. Samples were stored at $-20^{\circ} \mathrm{C}, 1$ hour after collection. They subsequently were freeze-dried, ground, and analyzed for organic nitrogen (A.O.A.C. 1970), digestible energy (Van Soest 1970; Bryant et al. 1980), and phosphorus (Murphy and Riley 1962). All hand-plucked samples were digested in vitro with innocula from one of the tame deer used in the study that was later fitted with a rumen cannula.

All data were subjected to analysis of variance using the general linear models procedure of Barr et al. (1976). A Duncan's multiple range test was used to evaluate differences among means between pastures only when the period $\times$ pasture interaction was significant (Dixon and Massey 1969).

\section{Results and Discussion}

\section{Forage Availability}

Average annual standing crop of grass on excellent condition range exceeded that on poor condition range by approximately $2,000 \mathrm{~kg} /$ ha (Table 2). The differences ranged from a high of 2,284 $\mathrm{kg}$ / ha in autumn 1975 , to $1,440 \mathrm{~kg} /$ ha in mid-summer, 1976. The excellent condition pasture had been rested from grazing during the period of March through June prior to initiation of the research, and abundant herbaceous material had accumulated. Grass standing crop on the excellent condition pasture was dominated by Texas cupgrass (Eriochloa sericea), common curly mesquite (Hilaria belangeri), cane bluestem (Bothriochloa barbinodis var. barbinodis), sideoats grama (Bouteloua curtipendula), and Texas wintergrass (Stipa leucotricha). During most months, these grasses comprised over $75 \%$ of the total grass standing crop. Whereas, on the poor condition pasture common curly mesquite, red grama (B. trifida), hairy tridens (Erioneuron pilosum), and Texas wintergrass supplied the most grass forage.

After 1-year of continuous grazing on the excellent condition site, grass standing crop had declined roughly $1,130 \mathrm{~kg} / \mathrm{ha}$ from the previous summer as a result of use by livestock and maturation of forage. However, significant recovery was expected because the livestock were removed on July 1 for a 4-month rest period and 28 $\mathrm{cm}$ of rain fell over a 25 -day period beginning July 4 . This unseasonably cool, rainy weather rejuvenated growth among all herbaceous species at a time when livestock use was excluded.

Forb standing crop over the year averaged six times more on excellent condition range than on poor condition range (Table 2). In every sampling period, forbs contributed more to the available forage on excellent condition range than poor. These standing crop estimates for forbs on the excellent condition site were higher than those recorded from a 40-year grazing exclosure (Smeins et al. 
Table 2. Forage biomass available (kg/ha) to white-tailed deer on excellent and poor condition range at the Sonora Research Station.

\begin{tabular}{|c|c|c|c|c|c|c|}
\hline & $\begin{array}{c}\text { Late summer } \\
\text { (August) } \\
1975\end{array}$ & $\begin{array}{c}\text { Autumn } \\
\text { (October) } \\
1975\end{array}$ & $\begin{array}{c}\text { Winter } \\
\text { (January) } \\
1976\end{array}$ & $\begin{array}{c}\text { Spring } \\
\text { (April) } \\
1976\end{array}$ & $\begin{array}{c}\text { Mid-summer } \\
\text { (July) } \\
1976\end{array}$ & Annual mean \\
\hline \multicolumn{7}{|l|}{ Grass: } \\
\hline Excellent condition & 3317 & 3235 & 2432 & 2586 & 2190 & 2752 \\
\hline Poor condition & 1090 & 951 & 707 & 335 & 790 & 775 \\
\hline \multicolumn{7}{|l|}{ Forb } \\
\hline Excellent condition & 476 & 79 & 30 & 62 & 259 & 181 \\
\hline Poor condition & 46 & 46 & 9 & 22 & 37 & 32 \\
\hline \multicolumn{7}{|l|}{ Browse: } \\
\hline Excellent condition & 576 & 618 & 534 & 445 & 391 & \\
\hline Poor condition & 2096 & 1924 & 1412 & 1019 & 1378 & 1566 \\
\hline \multicolumn{7}{|l|}{ Total: } \\
\hline Excellent condition & 4369 & 3932 & 2996 & 3093 & 2840 & 3446 \\
\hline Poor condition & 3232 & 2921 & 2128 & 1376 & 2205 & 2373 \\
\hline
\end{tabular}

1976) or from a non-rootplowed pasture also in the Merrill 4pasture, 3-herd grazing system (Reardon and Merrill 1976). Soil disturbance and subsequent aeration association with rootplowing probably contributed to the abundance of forbs on the good pasture, along with removal of competitive shrubs. However, proper grazing management following the treatment cannot be ignored as a significant factor in maintaining and promoting vigorous forb growth.

Powell and Box (1966) found rootplowing to have a positive influence on standing crop. If large blocks a re rootplowed, however, the impact on deer may be negative (Davis and Winkler 1968; McMahan and Inglis 1974). Urness (1974) reported mule deer $(O$.

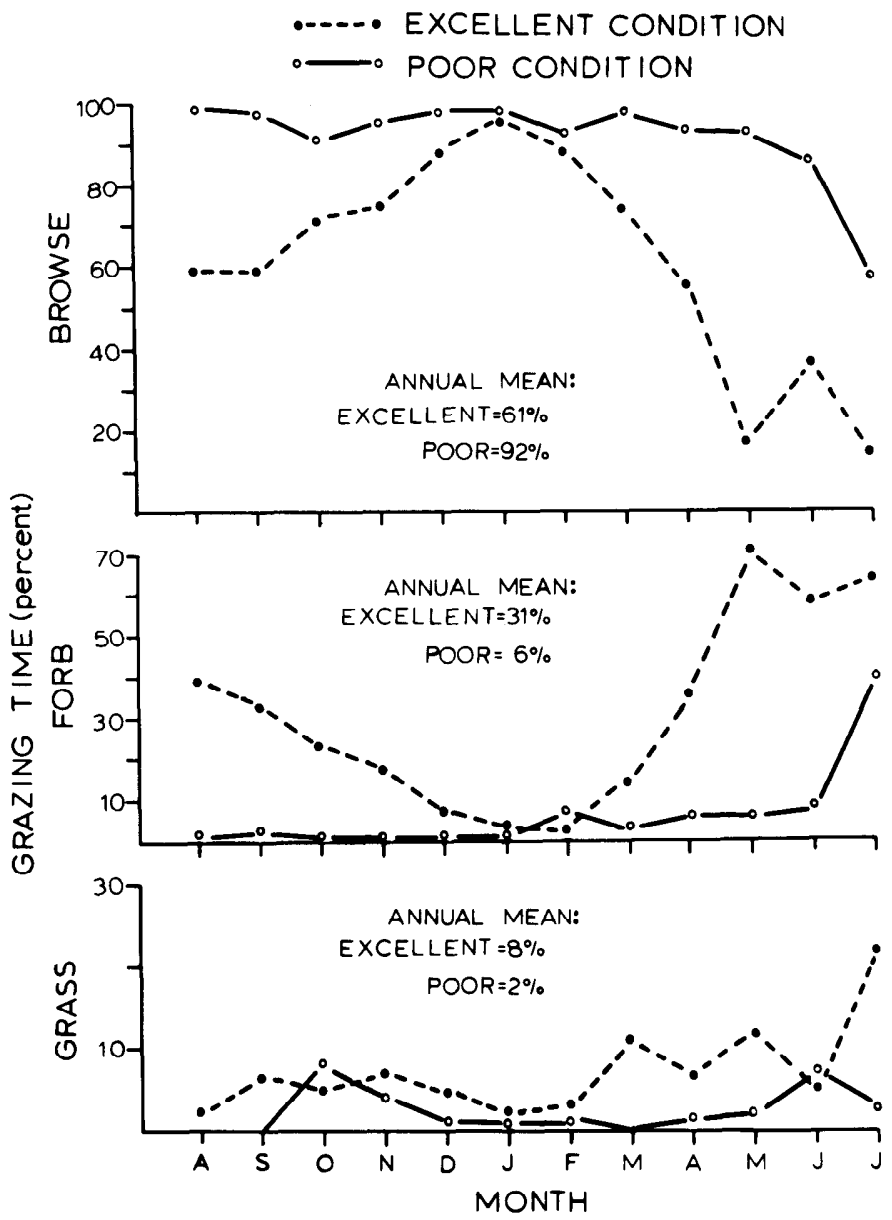

Fig. 2. Percent feeding time white-tailed deer spent on the major forage classes from excellent and poor condition range. hemionus) used rootplowed areas consistently less than adjacent, untreated brush. He suggested that when treatments left adequate cover, increased forbs on rootplowed areas would be highly beneficial to deer.

Some of the more abundant forb species on the excellent condition site were perennials including orange zexmenia (Zexmenia hispida), Plantago spp., Abutilon spp., Texas snoutbean (Rhynchosia texana), Lindheimer copperleaf (Acalypha lindheimeri), upright prairie-coneflower (Ratibida columnaris), spreading sida (Sida filicaulis), velvet bundleflower (Desmanthus velutinus), Mexican sagewort (Artemisia ludoviciana), and chickenthief mentzelia (Mentzelia oligosperma). These forbs comprised more than $77 \%$, and $53 \%$, and $74 \%$ of the forb standing crop in August, 1975, and April, and July 1976, respectively. On the poor condition range the palatable forbs recorded were spreading sida, Texas snoutbean, and velvet bundleflower, but were found only in limited amounts.

Availability of browse was three times greater on poor condition range than on excellent (Table 2). Most browse on the poor condition pasture was from mature plants, whereas rootplowing eliminated mature trees on the excellent condition pasture and the resulting browse was primarily from 7-year-old resprouts. Over $75 \%$ of the browse standing crop on the poor condition pasture was Juniperus spp., with Vasey shin oak (Quercus pungens var. vaseyana), and plateau oak (Quercus virginiana var. fusiformes) constituting most of the remaining $30 \%$. On the excellent condition pasture, plateau oak and Vasey shin oak co-dominated the browse standing crop.

\section{Forage Composition of Diets}

Deer spent more time $(P<0.05)$ feeding on grass on the excellent condition pasture than the poor condition pasture (Fig. 2). Highest grass use was from spring to early summer, similar to the findings of McMahan (1964). This period corresponds to the succulent growth stage of warm-season grasses. In south Texas, deer used more grass in winter than any other season (Chamrad and Box 1968; Drawe and Box 1968).

McMahan (1964) found deer took more 'bites' of grass under 'heavy' use by livestock than 'light' or 'no' use, and indicated they ate grass only when browse or forbs were lacking. Contrary to McMahan's findings, deer in the excellent condition pasture spent more than $22 \%$ of their time feeding on regrowth grass during July, a time when browse was abundant and forbs were rejuvenated by the unexpected rainfall. Most of their feeding time (18\%) was divided equally between Johnsongrass (Sorghum halepense) and cane bluestem. Since Johnsongrass is extremely palatable to most herbivores, it is rarely found in grazed pastures on the Edwards Plateau, except those that are well managed. The Merrill 4-pasture grazing system maintained this grass even at the heavy stocking rate ( $1 \mathrm{AU} / 5.2 \mathrm{ha})$. The remainder of the feeding time was distributed among fall witchgrass (Leptoloma cognatum), King Ranch bluestem (B. ischaemum var. songarica), tumblegrass (Schedonnardus paniculatus), sideoats grama and Carex spp. 
One of the deer fed mostly on Johnsongrass, while the other fed mostly on native grasses, primarily cane bluestem and sideoats grama. The high use of grass by deer was associated not only with above-average rainfall promoting grass regrowth, but with removal of the livestock that made the nutritious grass leaves available to deer. This succulent material was not as available on the excellent condition pasture and the poor condition pasture in spring nor the poor condition pasture in July because the livestock were present. Thus, these deer appeared to select grass when immature growth was readily available.

Grazing systems that provide for periodic resting of the range from domestic livestock are advantageous to deer because livestock can remove mature grass herbage during the grazing period and nutritious regrowth is readily available to deer during the rest period if growing conditions prevail. Fulgham et al. (1977) suggested controlled sheep grazing benefitted mule deer diets on foothill ranges in Utah because of succulent grass made available.

Forbs contributed more $(P<0.05)$ to the deer feeding time on the excellent condition pasture than on the poor condition pasture (Fig. 2). Increased use of forbs by deer as a vailability increased has been well documented (McMahan 1964; Chamrad and Box 1968; Drawe and Box 1968; McCollum 1972), and forbs were more a vailable on the excellent condition pasture (Table 2). Seasonally, however, forbs were highest in availability in autumn, 1975, but the greatest percentage of time deer spent feeding on forbs was in spring. Thus it appears that mature forbs in autumn, albeit abundant, were not as palatable to deer as were the forbs present in spring.

On the excellent condition pasture, forbs in deer diets declined in importance from autumn through winter but began to increase by March (Fig. 2). The highest percentages of time deer spent feeding on forbs were recorded from May through July. On the poor condition pasture, the only significant amount of time $(34 \%)$ deer spent on forbs was in July when availability of spreading sida increased in response to the cool, rainy weather and the deer actively grazed this species.

Some species selected by deer in this study were similar to those reported by McMahan (1964) and McCollum (1972). However, forb abundance and diversity in the excellent condition pasture provided deer a higher degree of selectivity. Consequently, preference indices on excellent condition range were different from those of McCollum (1972) and new species were added to our knowledge of plants palatable to deer (Table 3). Some species were highly preferred during some some seasons but ignored at other times of the year even though available. Artemisia ludoviciana and Ratibida columnaris are good examples. The study deer tested certain species only once but did not select them again. Examples are Hedyotis spp., Hymenoxys odorata, Evax prolifera, Croton spp., and Paronychia jamesii.

Preference indices are notably biased because it is difficult to show a high preference for an abundant species or a low preference for a scarce species. Zexmenia hispida was the most abundant forb and appeared to be highly palatable to the deer because of the observed high use. However, the average annual preference index was similar to Ratibida columnaris (Table 3). Preference indices of plants eaten by deer in this study (Table 3 ) are useful for intensive management in light of the potential of these plants for propagation and planting.

The amount of time deer spent feeding on browse was lower $(P<0.05)$ on the excellent condition pasture $(61 \%)$ when compared with browse feeding time $(92 \%)$ on the poor condition pasture (Fig. 2). Browse use on the poor condition pasture was high yearlong except in July when browse feeding time dropped to $58 \%$. Results from the poor condition pasture are similar to those McMahan (1964) reported from the pasture he labeled "heavy degree of use.' Feeding time on browse in the excellent condition pasture was comparable to results of McMahan's (1964) from the pasture labeled as 'no other use,' where deer spent most of their time feeding on browse only during winter. He suggested the greatest difference found in deer food habits occurred between the "no other se' pasture (exclosure) and any of the continuously grazed pastures, regardless of the degree of use.

Oak leaves were the most important browse constituent in deer diets on the excellent condition pasture, primarily because oak was the dominant browse available. Plateau oak was most heavily used in winter because of its evergreen nature, but also was important to deer in the other seasons. Vasey shin oak was important only in spring. Other browse species used throughout the year to a limited extent, primarily because of their low availability, were sugar hackberry (Celtis laevigata), woollybucket bumelia (Bumelia lanuginosa), Texas persimmon (Diospyros texana), and elbowbush (Forestiera pubescens).

On the poor condition pasture, browse use by deer included year-round use of plateau oak, early spring use of Vasey shin oak, and heavy winter use of decadent leaves of Texas persimmon, foliage of Ashe juniper (Juniperus ashei) and mast from Ashe juniper and redberry juniper ( $J$. pinchoti).

During February in the poor condition pasture, deer spent $34 \%$ ( $20 \%$ on green foliage and $14 \%$ on mast) of their time feeding on Ashe juniper. This heavy use was surprising since these tame deer were not under nutritional stress. In Arizona, Swank (1958) regarded Juniperus spp. as an unpalatable emergency food source for mule deer. In Texas, most biologists assume Juniperus spp. are relatively unpalatable and are not used much by white-tailed deer. However, for mule deer, Terrel and Spillett (1975) found Utah juniper ( $J$. osteosperma) comprised 20 to $25 \%$ of the overwinter diet in a Utah study and stated deer actually exhibited a certain degree of preference for it. Kufeld et al. (1973) also reported Utah juniper to be important in several mule deer diet studies in other states. Where identified, certain species of juniper, such as Ashe juniper in Texas, may thus be more palatable and important to deer than presently is realized. These results have far-reaching management implications. Complete eradication of Ashe juniper may influence deer not only in terms of cover lost but also in removal of a seasonally important food source.

\section{Nutrient Composition of Diets}

Deer diets from the pasture in excellent range condition were higher $(P<0.05)$ in crude protein throughout the year than diets from poor condition range (Fig. 3). Although the average annual difference was only $2.6 \%$, during several months the difference was considerably greater and approached $8.0 \%$ during May.

The maintenance requirement for protein is the amount necessary to cover nitrogen losses not of dietary origin, including metabolic fecal nitrogen and endogenous urinary nitrogen (Church et al. 1974). Dietz (1965) reported minimum protein levels for deer were thought to be around 6-7\% and Wallmo et al. (1977) used 7\% as the maintenance requirement for deer in their study. Milford and Haydock (1965) reported $7 \%$ crude protein was the minimum level required by sheep for positive nitrogen balance. Church et al. (1974) found $8 \%$ protein was needed for maximum cellulose digestion in lambs. Also of significance is the protein requirement for reasonable growth and production, quoted as being anywhere from 13 to $20 \%$ (Verme and Ullrey 1974).

Hand-plucked diet samples from the excellent condition pasture were never below $7 \%$ for crude protein in any month of the year but were below $8 \%$ in January and February (Fig. 3). Deer primarily ate plateau oak during these months. Huston (unpublished data) reported crude protein in leaves of plateau oak reached their lowest levels $(8.6 \%)$ during February. Deer in this study fed on twigs as well as leaves and the diets were hand-plucked to simulate this feeding behavior. Thus the estimates of $8 \%$ in this study seem realistic when compared with Huston's data. Also, Wilson et al. (1971) reported cut samples of shoots and leaves of interior live oak ( $Q$. wislizenii) were similar in crude protein to diet samples collected from sheep via esophageal fistulae. In terms of maintenance on the poor condition pasture, deer reached critically low levels $(6.1-7.4 \%)$ of crude protein during December and January.

If $13 \%$ crude protein is considered a minimum for reasonable production and growth, diets from the pasture in poor range 


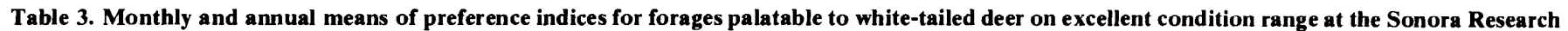
Station.

\begin{tabular}{|c|c|c|c|c|c|c|c|c|c|c|c|c|c|}
\hline & $\begin{array}{l}\text { Aug. } \\
1975\end{array}$ & Sept. & Oct. & Nov. & $\begin{array}{l}\text { Dec. } \\
1976\end{array}$ & Jan. & Feb. & Mar. & Apr. & May & June & July & Mean \\
\hline \multicolumn{14}{|l|}{ Grass and Grasslike Plants } \\
\hline Bothriochloa barbinodis & -9.2 & -9.2 & -9.4 & -9.3 & -9.2 & - & - & -9.0 & -9.1 & -9.6 & -9.3 & -2.2 & -8.5 \\
\hline Carex spp. & 9.5 & 8.1 & 7.9 & 7.2 & 7.4 & - & 8.2 & 8.4 & - & - & 6.9 & 7.3 & 7.9 \\
\hline Hilaria belangeri & - & - & - & - & - & - & -9.3 & - & - & - & - & - & -9.3 \\
\hline Leptoloma cognatum & -2.7 & - & - & - & - & - & -0.9 & - & - & - & - & 3.6 & 0.0 \\
\hline Sorghum halepense & -0.3 & 5.8 & 3.2 & -6.7 & 0.6 & -2.7 & - & 9.8 & 9.7 & 9.5 & 9.6 & 2.1 & 3.7 \\
\hline Bothriochloa ischaemum & - & - & - & - & - & - & - & -5.6 & -6.5 & -4.0 & - & -7.6 & -5.9 \\
\hline Schizachyrium scoparium & - & - & - & - & -6.5 & - & - & - & -7.3 & - & - & - & -6.8 \\
\hline Bouteloua curtipendula & - & - & - & -9.5 & -8.8 & - & - & -6.3 & -8.2 & - & - & -5.3 & -7.6 \\
\hline Eriochloa sericea & - & - & - & - & -9.7 & - & -9.8 & -9.5 & - & -9.7 & - & - & -9.7 \\
\hline Stipa leucotricha & - & - & -5.4 & 2.1 & -6.9 & -8.6 & 1.1 & -0.2 & - & -7.5 & - & - & -3.6 \\
\hline \multicolumn{14}{|l|}{ Forbs } \\
\hline Abutilon spp. & -3.2 & - & 9.6 & - & 9.3 & - & - & 9.2 & 9.8 & 9.3 & 7.6 & 7.3 & 7.4 \\
\hline Anemone spp. & - & - & - & 7.7 & - & - & - & - & - & - & - & - & 7.7 \\
\hline Astragalus spp. & 2.5 & - & - & - & - & 9.2 & - & - & 9.9 & 9.9 & 8.4 & - & 7.9 \\
\hline Simsia calva & - & 5.8 & 8.9 & - & - & - & - & 9.2 & 9.6 & 9.8 & 7.0 & 8.5 & 8.4 \\
\hline Evax prolifera & 0.8 & - & - & - & - & - & - & - & - & - & - & 0.9 & \\
\hline Tragia nepetaefolia & 4.8 & - & 9.4 & - & - & - & - & - & - & - & 3.9 & 8.5 & 6.6 \\
\hline Cocculas carolinus & - & - & - & - & - & - & - & - & 9.6 & 9.8 & 9.1 & 9.2 & 9.5 \\
\hline Mentzelia oligosperma & 9.8 & 9.5 & - & - & - & - & - & - & 9.8 & 9.0 & 9.2 & 7.6 & 9.1 \\
\hline Acalypha lindheimeri & 7.8 & 9.8 & 9.6 & - & 9.3 & - & - & 9.2 & 9.3 & 9.2 & 8.6 & 5.0 & 8.6 \\
\hline Croton spp. & 5.9 & - & - & - & - & - & - & - & - & - & - & - & 5.9 \\
\hline Verbena bipinnatifida & - & 8.9 & - & - & 9.3 & - & - & 9.3 & - & 9.6 & 8.4 & 9.2 & 9.1 \\
\hline Anethum graveolens & - & - & - & - & - & - & 9.1 & 8.4 & - & - & - & - & 8.7 \\
\hline Euphorbia spp. & 9.0 & - & - & - & - & - & - & - & - & 9.2 & 9.1 & 9.9 & 9.3 \\
\hline Siphonoglossa pilosella & & & 9.7 & & & - & - & - & & - & - & - & 9.7 \\
\hline Hedeoma spp. & 0.8 & 8.1 & - & - & 8.6 & 7.3 & - & - & - & - & - & - & 6.2 \\
\hline Hedyotis spp. & 5.9 & - & - & - & - & - & - & - & - & - & - & - & 5.9 \\
\hline Melampodium cinereum & - & - & 8.9 & - & - & - & - & - & - & 9.2 & - & 8.5 & 8.9 \\
\hline Paronychia jamesii & 9.0 & - & - & - & - & - & - & - & - & - & - & - & 9.0 \\
\hline Phyllanthus polygonoides & 8.8 & 8.9 & - & - & - & - & 9.1 & - & - & 2.8 & 7.0 & 4.3 & 6.8 \\
\hline Vicia leavenworthii & - & - & - & - & - & - & - & 9.2 & 9.3 & 9.2 & - & - & 9.2 \\
\hline Artemisia ludoviciana & 9.5 & - & - & 3.7 & 8.6 & 8.5 & 9.0 & 9.9 & 7.4 & - & - & - & 8.1 \\
\hline Mirabilis spp. & - & - & - & - & - & - & - & - & - & 1.1 & 9.1 & - & 5.1 \\
\hline Zexmenia hispida & -8.4 & 4.4 & 6.3 & -5.9 & 7.4 & - & - & 9.2 & 6.9 & 3.5 & 5.1 & 5.6 & 3.4 \\
\hline Oxalis spp. & - & - & - & 8.8 & 8.6 & - & 9.1 & - & 7.4 & 9.2 & - & 9.2 & 8.7 \\
\hline Plantago spp. & - & - & - & 9.9 & 7.4 & - & 6.7 & 7.1 & 4.6 & -0.1 & - & - & 5.9 \\
\hline Physalis spp. & - & 9.5 & 9.4 & 9.4 & 9.3 & 9.2 & 9.1 & 9.2 & 9.3 & 9.2 & - & - & 9.3 \\
\hline Portulaca spp. & - & - & - & - & - & - & - & - & - & - & - & 1.2 & 1.2 \\
\hline Lactuca serriola & - & - & - & 9.8 & 9.3 & - & - & 8.4 & 9.6 & 9.2 & - & - & 9.3 \\
\hline Salvia texana & - & 9.5 & - & 7.7 & - & - & - & 7.1 & 7.4 & 4.2 & 7.0 & 7.3 & 7.2 \\
\hline Galium virgatum & - & - & - & - & - & - & - & 8.4 & 8.6 & 2.8 & - & - & 6.6 \\
\hline Daucus pusillus & - & - & - & - & - & - & 8.2 & 9.2 & 7.4 & 7.2 & - & - & 8.0 \\
\hline Solanum spp. & - & - & - & - & - & - & - & 9.2 & 8.6 & 8.5 & 3.9 & - & 7.5 \\
\hline Sida filicaulis & 3.3 & 8.1 & 8.9 & - & - & - & - & - & - & 8.5 & 8.4 & 9.2 & 7.7 \\
\hline Gaillardia suavis & - & - & - & - & - & - & - & - & 9.3 & 7.2 & - & 9.2 & 8.6 \\
\hline Rhynchosia texana & 9.7 & 9.8 & 8.9 & 8.8 & - & - & - & 8.4 & 9.7 & 9.8 & 9.6 & 9.4 & 9.4 \\
\hline Clematis drummondii & 9.8 & 9.9 & 9.4 & 9.7 & - & & 9.1 & 9.2 & 9.3 & 7.2 & 8.4 & - & 9.1 \\
\hline Ratibida columnaris & -5.4 & - & 9.4 & 7.3 & 7.8 & 6.7 & 7.8 & 8.4 & 4.6 & 0.1 & -4.1 & -3.3 & 3.6 \\
\hline Desmanthus velutinus & 9.4 & 8.1 & 8.9 & - & - & - & - & 8.4 & 9.9 & 9.7 & 9.7 & 9.6 & 9.2 \\
\hline Hymenoxys odorata & - & - & - & - & - & - & $9-0$ & - & - & - & - & - & 9.0 \\
\hline Pinaropappus roseus & - & - & - & - & 7.4 & - & 8.2 & 8.4 & 9.3 & - & - & - & 8.3 \\
\hline \multicolumn{14}{|l|}{ Browse } \\
\hline Berberis trifoliolata & 9.2 & - & - & - & - & - & - & 8.7 & - & - & - & - & 8.9 \\
\hline Acacia greggii & 9.9 & 9.9 & 9.9 & - & - & - & - & 9.2 & 9.9 & 9.8 & 9.8 & 9.8 & 9.8 \\
\hline Forestiera pubescens & 9.8 & 9.8 & 9.8 & - & - & - & - & 9.8 & 9.9 & - & - & 9.5 & 9.8 \\
\hline Prosopis glandulosa & 9.5 & - & - & - & - & - & - & - & 9.3 & 8.5 & 8.4 & 8.5 & 8.8 \\
\hline Quercus virginiana & 8.2 & 7.7 & 84. & 8.5 & 9.1 & 9.3 & 9.4 & 6.5 & 8.4 & 4.2 & 6.8 & 1.4 & 7.3 \\
\hline Rhus aromatica & 9.9 & 9.9 & 9.9 & - & - & - & - & - & 9.9 & 9.8 & & - & 9.9 \\
\hline Celtis laevigata & 9.9 & 9.7 & 9.7 & - & 9.3 & - & - & 9.2 & 9.9 & 9.9 & 9.9 & 9.9 & 9.7 \\
\hline Diospyros texana & - & 8.9 & 8.9 & - & - & - & - & 8.1 & 9.9 & 9.2 & 9.4 & 7.3 & 8.8 \\
\hline Quercus pungens & 9.6 & 9.9 & 9.9 & 9.8 & 8.6 & 9.6 & 9.9 & 9.9 & 9.5 & 8.5 & 9.3 & 7.3 & 9.3 \\
\hline Bumelia lanuginosa & 9.0 & 9.9 & 99 & 9.9 & - & - & - & 9.2 & 9.9 & - & 9.9 & - & 9.8 \\
\hline
\end{tabular}




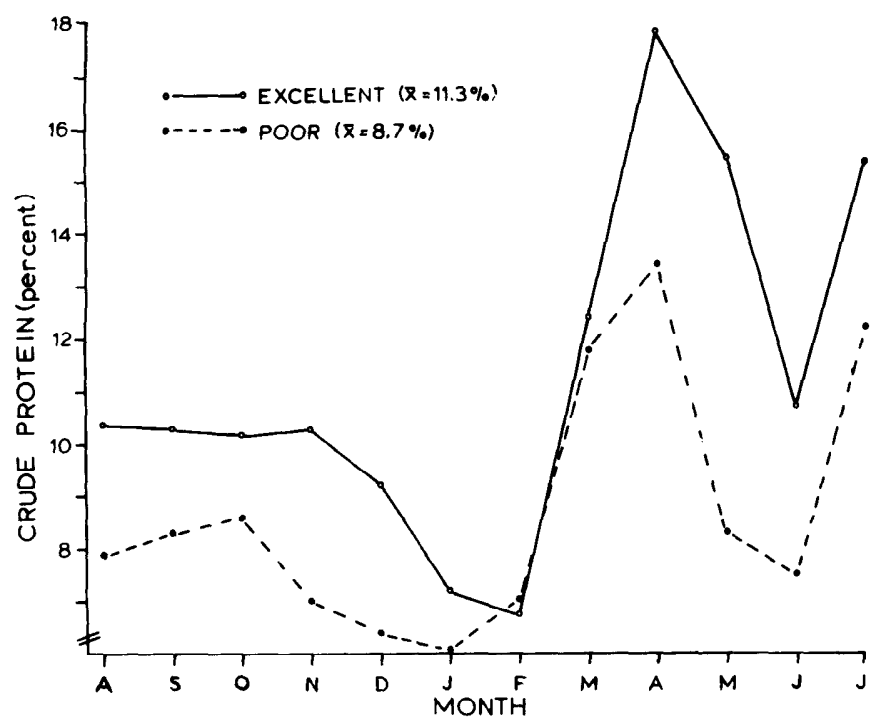

Fig. 3. Percent crude protein in samples hand-plucked to simulate diets selected by deer from pastures in excellent and poor range condition at the Sonora. Research Station.

condition were below that level in every month but April, whereas, on excellent condition range, they were at or above that level during March, April, May, and again in July. Hand-plucked diets approached $18 \%$ crude protein during April on the excellent condition pasture. Further, diets from excellent condition range were higher $(P<0.05)$ than those from poor condition in every month of the year but February and March.

Average annual digestible energy levels in deer diets were not different $(P>0.05)$ between the two pastures (Fig. 4). However, during late summer 1975 and spring and early summer 1976, digestible energy levels were higher $(P<0.05)$ from diet samples hand-plucked from the excellent condition pasture. This was attributed to deer spending more time feeding on forbs and grasses on the excellent condition pasture (Fig. 2).

From December through March, digestible energy levels were higher $(P<0.05)$ in diet samples from the poor condition pasture. Deer spent $85 \%$ to $95 \%$ of their time feeding on browse in both past ures and usually, high amounts of browse in diets results in low digestibility (Wilson et al. 1971). However, different browse species

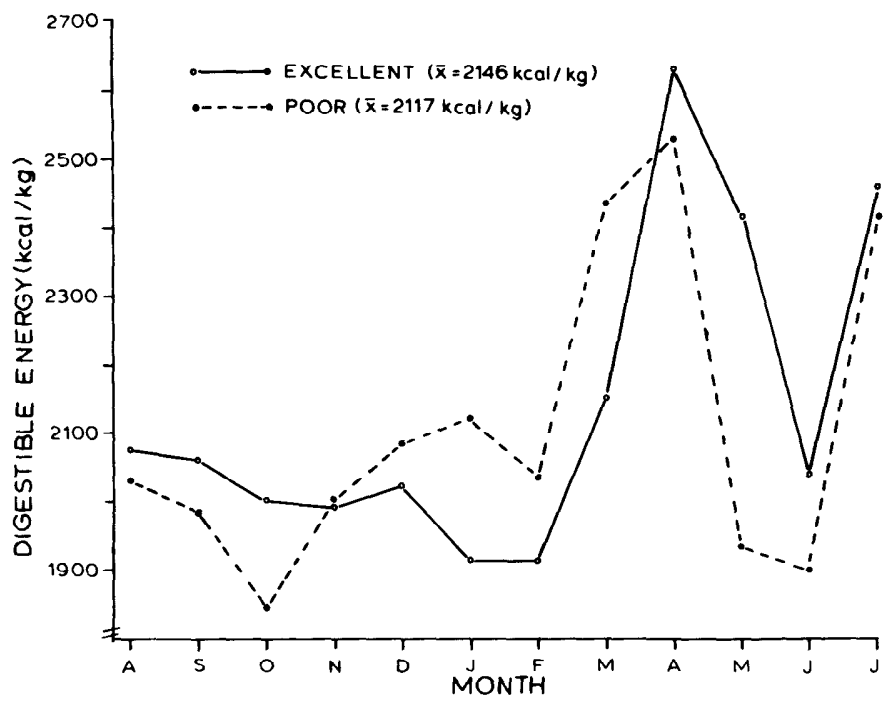

Fig. 4. Digestible energy $(\mathrm{kcal} / \mathrm{kg})$ in samples hand-plucked to simulate diets selected by deer from pastures in excellent and poor range condition at the Sonora Research Station. supply nutrients in differing amounts (Wilson 1969). When grazed on the pasture in excellent range condition, the deer fed primarily on foliage of plateau oak. Oak leaves and twigs notoriously are poor energy sources because they have highly lignified cell walls (Wilson et al. 1971), which depresses digestibility (Van Soest 1967) and thus, total intake (Bissell and Strong 1955).

Browse species other than plateau oak were eaten by deer on the pasture in poor range condition. These included foliage and mast from juniper and fallen leaves of Texas persimmon.

Juniper contains volatile oils that may inflate energy values. These oils, extracted in the laboratory as organic matter that are actually part of the ether extract fraction, are largely non-nutritive (M.M. Kothmann pers. comm.). Short et al. (1966) found ether extract to be as high as $15-19 \%$ in Rocky Mountain juniper ( $J$. scopulorum), while Fraps and Cory (1940) reported values of 9-11\% for redberry juniper but they did not analyze Ashe juniper. Thus, all samples containing juniper were analyzed for ether extract (A.O.A.C. 1970) and corrected for ether extract content. The results suggest that complete eradication of Ashe juniper may remove a potentially important energy source because winter energy values were still higher on the poor condition pasture. However, energy from Ashe juniper may only be supplemental if its volatile oils inhibit rumen function when the plant is consumed in large quantities. This inhibiting affect has been reported for other junipers (Dietz and Nagy 1976) as well as for other genera containing high percentages of volatile oils (Nagy and Tengerdy 1968; Oh et al. 1968).

Male and female white-tailed deer fawns require 168 and 155 $\mathrm{kcal} / \mathrm{kg} \mathrm{BW}^{0.75} /$ day of digestible energy for maintenance, respectively (Ammann et al. 1973). A male fawn weighing $18 \mathrm{~kg}$ in October would require $1,468 \mathrm{kcal}$ of digestible energy per day. Respective estimates of the supply of energy for the fawn eating 32 $\mathrm{g} / \mathrm{kg}$ of BW/day (Wallmo et al. 1977) on the excellent and poor condition pastures would be 1,162 and $1,043 \mathrm{kcal} /$ day, assuming the fawn had stopped nursing. The resulting deficiency would be 305 and $375 \mathrm{kcal} /$ day on the excellent and poor condition pastures, respectively. Similarly computed for $18 \mathrm{~kg}$ female fawns, the deficiency would be 193 and $262 \mathrm{kcal} /$ day on the excellent and poor condition pastures, respectively. Since energy and not protein affects ovulation in female fawns (Abler et al. 1976), the observed energy shortages could affect herd reproduction.

A weaned $20-\mathrm{kg}$ male fawn in January would be deficient 361 and $248 \mathrm{kcal} /$ day of digestible energy on the good and poor pastures, respectively. These results likely overestimate deficiencies because diet selectivity by deer is much more refined than man can simulate. Regardless, the increased energy demands of growth over maintenance (Thompson et al. 1973) suggests energy may be a major limiting nutrient for fawns under the conditions of this study.

A 45-kg pregnant doe in May, eating $22 \mathrm{~g} / \mathrm{kg}$ of BW/day (Wallmo et al. 1977) with a requirement of $156 \mathrm{kcal} / \mathrm{kg} \mathrm{BW}^{.75} / \mathrm{day}$ (Ullrey et al. 1969), would be $781 \mathrm{kcal} /$ day below her digestible energy requirement on the poor condition pasture and only 318 $\mathrm{kcal} /$ day below on the excellent condition pasture. This difference was attributed to the increased use of forbs and grasses on the excellent condition pasture.

Although there are no estimates of digestible energy requirements for deer during lactation, requirements for sheep may increase as much as $500 \mathrm{kcal} / \mathrm{kg}$ of dry matter in the diet (NRC 1975). This is important because digestible energy levels in diet samples dropped on both pastures during June, a time when white-tailed deer on the Edwards Plateau normally are in heavy lactation. Levels were nearly as low in June as they were in late autumn and early winter, periods of record lows for digestible energy.

The results of insufficient energy in lactating ewes were lower milk production and a shortened lactation period (Pope 1974). Further, dairy cattle decreased both milk production and feed consumption when environmental temperatures increased (Ragsdale et al. 1948). When temperatures reach and continue at $38^{\circ} \mathrm{C}$, 


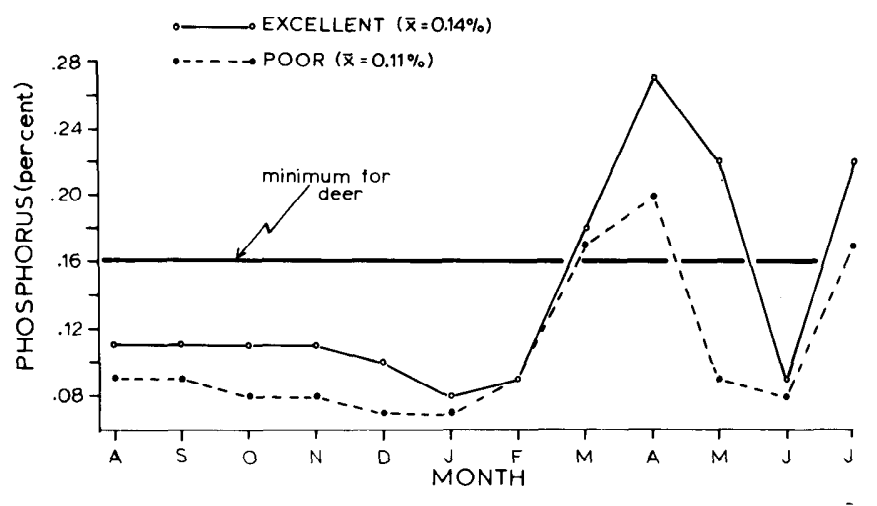

Fig. 5. Percent phosphorus in samples hand-plucked to simulate diets selected by deer from pastures in excellent and poor range condition at the Sonora Research Station.

dairy cattle may even stop milk production. Thus, energy shortages during hot summers may contribute to death of young deer on these ranges through a decreased energy supply in the face of rising energy demands for both the doe and fawn. Fawns apparently can shunt a limited food intake into fat reserves when growth is no longer possible (Verme and Ullrey 1974). This may enable some young deer to survive such conditions. High levels of digestible energy observed in July were abnormal because of the cool, rainy weather that prevailed.

Levels of phosphorus in hand-plucked diets were higher $(P<0.05)$ on the excellent condition pasture than the poor condition pasture when averaged over the year (Fig. 6). This difference was attributed primarily to differences $(P<0.05)$ between pastures during April, May, and July.

Dietz (1965) and Short (1969) a gree that phosphorus intake at or below $0.16 \%$ could adversely affect reproduction. Others feel $0.25 \%$ is necessary for normal development (French et al. 1956; Ullrey et al. 1973). Verme and Ullrey (1974) reported excellent development of fawns when fed a ration containing $0.35 \%$ phosphorus.

None of the estimates approached $0.35 \%$ phosphorus in either pasture and the $0.25 \%$ level was exceeded during April only on the excellent condition pasture. Hand-plucked diets exceeded $0.16 \%$ during 4 months of the year on the excellent condition pasture but were above that level in only 3 months on the poor condition pasture. The lowest levels of phosphorus corresponded to high amounts of feeding time deer spent on browse, except in early spring when high phosphorus levels were observed in addition to high use of browse. This agrees closely with Wilson's (1969) report that non-deciduous shrubs were usually low in phosphorus with their highest amounts occurring in spring.

\section{Conclusion}

McMahan (1964) concluded that the greatest differences in food habits of deer occurred between a grazing exclosure and continously stocked pastures regardless of stocking rate. The results presented in this paper indicate that a stocked pasture in excellent range condition was comparable in terms of deer food habits to McMahan's (1964) data from an area where livestock were excluded. The grazing system observed in this study apparently contributed to and maintained the excellent range condition. Results were higher annual levels of crude protein and phosphorus and higher seasonal levels of digestible energy in simulated deer diets, as compared with poor condition range. Periodic resting of the range from domestic livestock apparently was advantageous to deer in this study because of reduced competition for succulent regrowth grass when growing conditions prevailed.

Diversity and abundance of grass, forb, and browse species seems desirable for higher quality deer diets on the Edwards Plateau of Texas. The appropriate spatial arrangement of these food sources for optimum deer habitat, along with the ability of deer to adapt to higher stages in plant succession, require further investigation.

\section{Literature Cited}

Abler, W.A., D.E. Buckland, R.L. Kirkpatric, and P.F. Scanlon. 1976. Plasma progestins and puberty in fawns as influenced by encrgy and protein. J. Wildl. Manage. 30:442-446.

Ammann, A.P., R.L. Cowan, C.L. Mothershead, and B.R. Baumgardt. 1973. Dry matter and energy intake in relation to digestibility in whitetailed deer. J. Wildl. Manage. 37:195-201.

Association of Official Agricultural Chemists. 1970. Official methods of analysis. (11th ed.) Ass. Off. Agr. Chem., Washington, D.C. 1015 p.

Barr, A.J., J.H. Goodnight, J.S. Sall, and J.T. Helwig. 1976. A user's guide to S.A.S. 76. SAS Institute Inc., Raleigh, N.C. 329 p.

Bissell, H.D., and H. Strong. 1955. The crude protein variations in the browse diet of California deer. California Fish and Game 41:145-155.

Bjugstad, A.J., H.S. Crawford, and D.L. Neal. 1970. Determining forage consumption by direct observation of domestic grazing animals. p. 101104. In: Range and Wildlife Habitat Evaluation. U.S. Dep. Agr. Forest Serv. Misc. Pub. No. 1147. 220 p.

Bryant, F.C., and M.M. Kothmann. 1979. Variability in predicting edible browse from crown volume. J. Range Manage. 32:144-146.

Bryant, F.C., M.M. Kothmann, and L.B. Merrill. 1980. Nutritive levels in sheep, goat, and white-tailed deer diets on excellent condition rangeland in Texas. J. Range Manage. 33:410-414.

Chamrad, A.D., and T.W. Box. 1968. Food habits of white-tailed deer in South Texas. J. Range Manage. 21:158-164.

Church, D.C., G.E. Smith, J.P. Fontenot, and A.T. Ralston. 1974. Digestive Physiology and Nutrition of Ruminants. Vol. Il. Nutrition 401-685.

Davis, A.B., and C.K. Winkler. 1968. Brush vs. cleared range as deer habitat in southern Texas. J. Wildl. Manage. 32:321-329.

Dietz, D.R. 1965. Deer nutrition research in range management. Trans. North Amer. Wildl. Nat. Res. Conf. 30:274-285.

Dietz, D.R., and J.G. Nagy. 1976. Mule deer nutrition and plant utilization. p. 71-78. In: G.W. Workman and J.B. Low (Eds.). Mule deer Decline in the West. Utah Agr. Exp. Sta. Sym. Proc. 134 p.

Dixon, W.J., and F.J. Massey. 1969. Introduction to Statistical Methods. McGraw-Hill Book Co. 637 p

Drawe, D.L., and T.W. Box. 1968. Forage ratings for deer and cattle on the Welder Wildlife Refuge. J. Range Manage. 21:225-228.

Durham, A.J., Jr., and M.M. Kothmann. 1977. Forage availability and cattle diets on the Texas coastal prairie. J. Range Manage. 30:103-106.

Fraps, G.S., and V.L. Cory. 1940. Composition and utilization of range vegetation of Sutton and Edwards counties. Tex. Agr. Exp. Sta. Bull. 586. $33 \mathrm{p}$.

French, C.E., L.C. McEwan, N.D. Magruder, R.H. Ingram, and R.W. Swift. 1956. Nutrient requirements for growth and antler development in the white-tailed deer. J. Wildl. Manage. 20:221-232.

Fulgham, K.O., J.C. Malechek, and M.A. Smith. 1977. Forage quality of a deer winter range grazed by sheep. Proc. 30th Annual Meeting Soc. Range Manage., Portland, Ore. p. 56 (abstract).

Goebel, C.J., L. DeBano, and R.D. Lloyd. 1958. A new method of determining forage cover and production on desert shrub vegetation. J. Range Manage. 11:244-246.

Krebs, C.J. 1972. Ecology: the Experimental Analysis of Distribution and Abundance. Harper and Row, Pub. New York. 694 p.

Kufeld, R.C., O.C. Wallmo, and C. Feddema. 1973. Foods of the Rocky Mountain mule deer. U.S. Dep. Agr. Forest Serv., Rocky Mt. Forest and Range Exp. Sta. Res. Pap. RM-111. 31 p.

Malechek, J.C., and C.L. Leinweber. 1972. Forage selectivity by goats on lightly and heavily grazed ranges. J. Range Manage. 25:105-111.

Marburger, R.G., and J.W. Thomas. 1965. A die-off in white-tailed deer of the central mineral region of Texas. J. Wildl. Manage. 29:706-716.

McCollum, J.M. 1972. The botanical composition of the diet of whitetailed deer. M.S. Thesis, Texas A\&M Univ., College Station. 51 p.

McMahan, C.A. 1964. Comparative food habits of deer and three classes of livestock. J. Wildl. Manage. 28:798-808.

McMahan, C.A., and C.W. Ramsey. 1965. Response of deer and livestock to controlled grazing in central Texas. J. Range Manage. 18:1-7.

McMahan, C.A., and J.M. Inglis. 1974. Use of Rio Grande plain brush types by white-tailed deer. J. Range Manage. 27:369-374.

Merrill, L.B., J.G. Teer, and O.C. Wallmo. 1957. Reaction of deer populations to grazing practices. Tex. Agr. Prog. 3:10-12.

Milford, R., and K.P. Haydock. 1965. The nutritive value of protein in subtropic pasture species grown in southeast Queensland. Aust. J. Exp. Sta. Agr. Anim. Husb. 5:13-17. 
Murphy, J., and J.P. Riley. 1962. A modified single solution method for the determination of phosphate in natural water. Anal. Chem. Acta. 27:3136.

Nagy, J.G., and R.P. Tengerdy. 1968. Antibacterial action of essential oils of Artemisia as an ecological factor. II. Antibacteria action of the volatile oils of Artemisia tridentata (Big sagebrush) on bactcria from the rumen of mule deer. Appl. Microbiol. 16:441-444.

National Research Council. 1975. Nutrient requirements of domestic animals; No. 5 Nutrient requirements of sheep. Nat. Academy of Sciences. 72 p.

Oh, H.K., M.B. Jones, and W.M. Longhurst. 1968. Comparison of rumen microbial inhibition resulting from various essential oils isolated from relatively unpalatable plant species. Appl. Microbiol. 16:39-44.

Pope, A.L. 1974. Feeding and nutrition of ewes and rams. p. 250-260. In: D.C. Church, (Ed.). Digestive Physiology and Nutrition of Ruminants. Vol. III. Pract. Nutr. 351 p.

Powell, J., and T.W. Box. 1966. Brush management influences preference values of South Texas woody species for deer and cattle. J. Range Manage. 19:212-214.

Ragsdale, A.C., S. Brody, H.J. Thompson, and D.M. Worstell. 1948. II. Influence of temperature $50^{\circ} \mathrm{F}$ to $105^{\circ} \mathrm{F}$, on milk production and feed consumption of dairy cattle. Mo. Agr. Exp. Sta. Bull. No. 425.

Reardon, P.O., and L.B. Merrill. 1976. Vegetative response under various grazing management systems in the Edwards Plateau of Texas. J. Range Manage. 29:195-198.

Reardon, P.O., L.B. Merrill, and C.A. Taylor, Jr. 1978. White-tailed deer preferences and hunter success under various grazing systems. J. Range Manage. 31:40-42.

Short, H.L., D.R. Dietz, and E.E. Remmenga. 1966. Selected nutrients in mule deer browse plants. Ecology 47:222-229.

Short, H.L. 1969. Physiology and nutrition of deer in southern upland forests. p. 14-18 In: L.K. Halls (Ed.). White-tailed Deer in the Southern Forest Habitat. U.S. Dep. Agr. Forest Serv., Southern Forest Exp. Sta. Symp. Proc. $130 \mathrm{p}$.

Smeins, F.E., T.W. Taylor, and L.B. Merrill. 1976. Vegetation of a 25-year exclosure on the Edwards Plateau of Texas. J. Range Manage. 29:24-29.
Swank, W.G. 1958. The mule deer in Arizona chaparral. Ariz. Game and Fish Dep., Wildl. Bull. No. 3. 9 p.

Teer, J.G., J.W. Thomas, and E.A. Walker. 1965. Ecology and management of the white-tailed deer in the Llano Basin of Texas. Wildl. Monogr. 15. $62 \mathrm{p}$.

Terrel, T.L., and J.J. Spillet. 1975. Pinyon-juniper conversion: Its impact on mule deer and other wildlife. p. 105-120. In: G.F. Gifford and F.E. Busby (Eds.). The Pinyon-Juniper Ecosystem: A Symposium. Itrah State Univ., Utah Agr. Exp. Sta., Logan. 194 p.

Thompson, C.B., J.B. Holter, H.H. Hayes, H. Silver, and W.E. Urban, Jr. 1973. Nutrition of white-tailed deer. I. Energy requirements of fawns. J. Wildl. Manage. 37:301-311.

Ullrey, D.E., W.G. Youatt, H.E. Johnson, L.D. Fay, B.L. Schoepke, W.T. Magee, and K.K. Keahey. 1973. Calcium requirements of weaned whitetailed deer fawns. J. Wildl. Manage. 27:187-194.

Ullrey, D.E., W.G. Youatt, H.E. Johnson, L.D. Fay, B.L. Schoepke, and W.T. Magee. 1969. Digestible energy requirements for winter maintenance of Michigan white-tailed does. J. Wildl. Manage. 33:482-490.

Urness, P.J. 1974. Deer use changes after rootplowing in Arizona chaparral. U.S. Dep. Agr. Forest Serv., Rocky Mt. Forest and Range Exp. Sta. Res. Note RM-225. 8 p.

Van Soest, P.J. 1970. Chemical basis for the nutritional evaluation of forages. Proc. Nat. Conf. on Forage Qual. Eval. and Util., Lincoln, Neb. 1969. U1-U19.

Van Soest, P.J. 1967. Development of a comprehensive system of feed analysis and its application to forages. J. Anim. Sci. 26:119-128.

Verme, L.J., and D.E. Ullrey. 1974. Feeding and nutrition of deer. p. 275-291. In: D.C. Church (Ed.). Digestive Physiology and Nutrition of Ruminants. Vol. III. Pract. Nutr. 351 p.

Wallmo, O.C., L.H. Carpenter, W.L. Regelin, R.B. Gill, and D.L. Baker. 1977. Evaluation of deer habitat on a nutritional basis. J. Range Manage. 30:122-127.

Wilson, A.D., W.C. Weir, and D.T. Torrell. 1971. Comparison of methods of estimating the digestibility of range forage and browse. J. Anim. Sci. 32:1046-1050.

Wilson, A.D. 1969. A review of browse in the nutrition of grazing animals. J. Range Manage. 22:23-28.

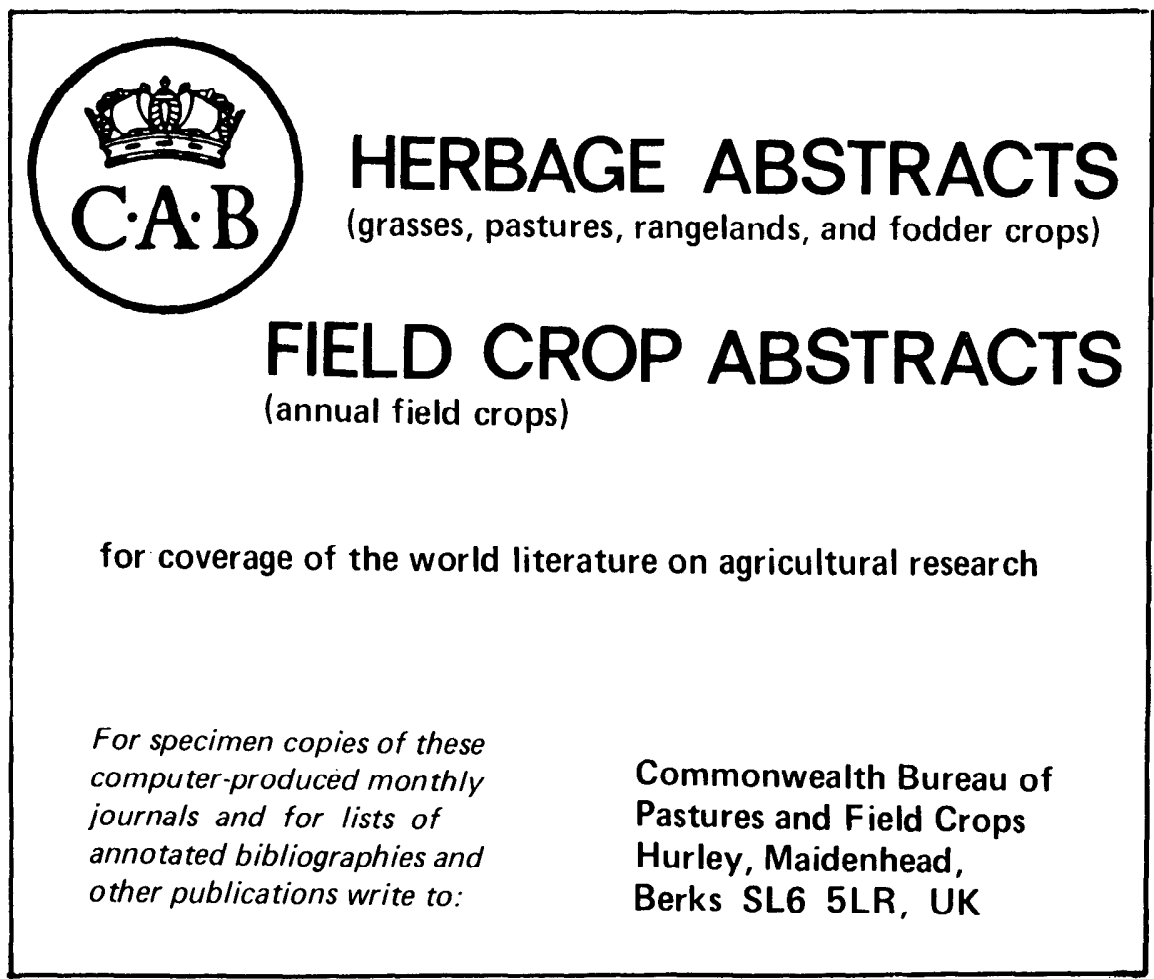

